\title{
黒毛和種牛，ホルスタイン種牛におけるグルコース静脈内注入が 代謝ホルモンに与える影響
}

\author{
佐藤秀俊* \\ 宮城県畜産試験場, 宮城県岩出山町 989-6445 \\ 1) 東北大学農学部，仙台市青葉区 981-0914
}

(1997. 10. 2 受付)

\begin{abstract}
要 約 ウシのグルコースの利用性について, 品種間差（未経産の黒毛和種牛掞よびホルスタイン種 牛), 汹乳期間差（泌乳期の異なるホルスタイン種牛）をグルコースの静脈内注入後の血中グルコース消 失率および血漿ホルモン分泌反応から检討した，グルコ一ス注入によりインスリン，グルカゴン，成長 ホルモン（GH）の分泌が有意に促進されたが，インスリン様成長因子-I（IGF-I）については变化が認 められなかった。 また，品種間差はなかったが，泌乳期ごとに固有の変動を示した．グルコース注入に 対する各ホルモンの血中濃度曲線下面積 (AUC) は, 黒毛和種牛でホルスタイン種牛よりあインスリン, グルカゴンが大きく，GH, IGF-Iが小さかった。また，ホルスタイン種牛で泌乳期の進行に伴い，インス リン,グルカゴンが大きくなり，GH, IGF-I が小さくなった，以上の結果，グルコース注入に対して品 種、泌乳期で固有の反応を示すことが明らかになった。
\end{abstract}

日畜会報，69(5) : 475-482, 1998

ウシの産肉，産乳を特徵つけけている栄養素の利用性と その分配は分婏と泌乳によって劇的に変化することが報 告さ机ている ${ }^{1,3)}$. 乳牛においては, 乳生産亡血中インス リン,グルカゴン，成長ホルモン (GH) 濃度之は一定の 関係があるこ上が報告されている9 ンは重要なホルモンの一つで, 乳生産に栄養素の利用を 最大限向りるため血中濃度が泌乳時期により異なること が報告されている ${ }^{19,22)}$. しかし，インスリンと同様に策 篒素の利用と分配に関係しているグルカゴン， $\mathrm{GH}$, イン スリン様成長因子-I (IGF-I) については品種間, 泌乳時 期により比較した報告は少ない行6,21). 特に，わが国で肉 專用種として一般的に飼養されている黒毛和種雌牛につ いての検討はない。

本研究の目的は, 産肉性を中心に改良されてきた, 肉 尃用種の黒毛和種牛 (未経産) および産乳性を中心に改 良されてきた，乳用種のホルスタイン種牛 (未経産) に ついてグルコースの静脈内注入に伴う血漿ホルモンの分 泌能とグルコースの消失率汃らグルコースの利用性を検 討することで品種の特性を調へ，さらに泌乳時期が比較 的明確で，控乳作業に馴馳したホルスタイン種牛を用
い, 泌乳期の進行にとあなう变化を同様に検討すること である.

\section{材料および方法}

実験に结，黒毛和種未経産4 4 頭（平均体重 $424 \pm 29$ $\mathrm{kg}$, 月齢 22 力月), ホルスタイン種未経産牛 4 頭 (平均 体重 $603 \pm 13 \mathrm{~kg}$, 月秢 22 力月), ホルスタイン種経産牛 15 頭（乾乳期 5 頭: 平均体重 $760 \pm 27 \mathrm{~kg}$ : 平均産次 2.2 産, 䎵乳中期 5 頭: 平均体重 $638 \pm 22 \mathrm{~kg}$ : 平均産次 2.8 産: 分娭後平均 92 日, 泌乳後期 5 頭: 平均体重 $690 \pm 42$ $\mathrm{kg}$ : 平均産次 2.8 産 : 分娩後平均 260 日）の計 23 頭を供 試した．飼料は，日本飼養標準に基づき，一日量を $8: 30$ と17:00に分け給与した ${ }^{11-13)}$. すなわち, 黒毛和種末経 産牛については肉牛用配合飼料（可消化粗タンパク質 $(\mathrm{DCP})>140 \mathrm{~g} / \mathrm{kg}$, 可消化養分総量 $(\mathrm{TDN})>670 \mathrm{~g} /$ $\mathrm{kg})$ ，オーチャードグラスとイタリアングラスの混播乾 草 $(\mathrm{DCP}>100 \mathrm{~g} / \mathrm{kg}, \mathrm{TDN}>610 \mathrm{~g} / \mathrm{kg})$ を給与した。. 木 ルスタイン種未経産牛, 経産牛については乳牛用配合飼 料 $(\mathrm{DCP}>140 \mathrm{~g} / \mathrm{kg}, \mathrm{TDN}>700 \mathrm{~g} / \mathrm{kg})$, 混播乾草を給与 した，さらに，泌乳期に応じてトウモロコシサイレージ

*現所属: 宮城県迫地域農業改良普及センター, 宮城県迫町 987-0511 
$(\mathrm{DCP}>70 \mathrm{~g} / \mathrm{kg}, \mathrm{TDN}>700 \mathrm{~g} / \mathrm{kg})$ を給与した．飲水は 自由とした。推乳牛については 8:00 と $16: 30$ に揞乳し た. 実験は 10:00から開始した。

\section{グルコースの注入と探血}

グルコースの利用性から品種, 泌乳期での代謝ホルモ ン分泌を比較する日的で，グルコース（50\%溶液 : 大塚 製楽）を頸静脈にあらかじ的装着したカテーテルから速 やかに体重 $\mathrm{kg}$ あたり $0.625 \mathrm{mmol}$ 注入した。血液サン プルは, グルコース注入前 15 分, 開始直前, 注入開始後 $5 ， 10 ， 15 ， 30 ， 45 ， 60 ， 90$ および 120 分に頸静脈に装着

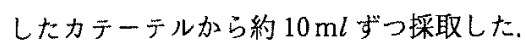

\section{測定項目および方法}

採取した血液は $4^{\circ} \mathrm{C} ， 3,000 \mathrm{rpm}$ で 15 分間遠心分離 後, 直ちに血嶈として $-30^{\circ} \mathrm{C}$ にて測定まで凍結保存し た。また，グルコース測定用試料については除タンパク 後, 凍結保存した。湘定項目および方法は，グルコース を醉素法（グルコースCテスト，和光純菜）にて，イン スリン,グルカゴン, GH, IGF-I は，それぞれ，東北大学 農学部動物生理科学教室で通常用いられている, ラジオ イムノアッセイ (RIA) ${ }^{14)}$ にて測定した.

すなわち，インスリンは，抗インスリン血清（antibovine insulin serum, 生化学工業), 標準インスリン (bovine insulin, Sigma, USA, lot28c-0136) および
[ $\left.{ }^{125} I\right]$ インスリン (Dupont, USA) を用い，デキストラ ンコートチャコール (DCC) 法により測定した。

グルカゴンは，抗グルカゴン血清（大根田らが作成し た膵グルカゴンに特異性の高い $\mathrm{G} 42 \mathrm{E}^{\mathrm{i6})}$ )，標準グルカ ゴン (porcine pancreas, SIGMA, USA)，および [125I] グルカゴン (Dupont, USA)を用い，DCC 法により測定 した。

GH は，抗 GH 血清 （anti-ovine serum，NIDDKAnti-oGH-2)，アイソトープ標識用 GH, 標準 GH （NIDDK-OGH-1-3）を用い，2 抗体法により测定した。 [ $\left.{ }^{125} \mathrm{I}\right] \mathrm{GH}$ はクロラミンT法にて作成した.

IGF-I は，血整を酸・エタノール処理して結合タンパ ク加分分離後, 抗 IGF-I 血清（anti-rabit serum, UB 2495), 標準 IGF-I (human recombinant, 東洋紡), [ ${ }^{125}$ I] IGF-I (human recombinant, Dupont, USA) を 用い，2抗体法により測定した.

\section{各種ホルモンの血中濃度下面皘とグルコース消失率の} 算出

インスリン，成長ホルモン，IGF-I，グルカゴンの血中 濃度曲線下面皘（the area under the curve; AUC, 濃度 0 以上) は, 注入後 0 から 120 分について計算し, 表 1 に 示した。 また，グルコースの利用率は，グルコース消失 定数 (K)により示し，次式をもとに計算した20).

Table 1a. Summary of the area under the curve (AUC) of plasma insulin, glucagon, growth hormone $(\mathrm{GH})$, insulin-like growth factor I (IGF-I) at glucose responses to glucose challenges and rate of glucose disapperance rates $(\mathrm{K})$ in Japanese Black heifers and Holstein heifers

\begin{tabular}{|c|c|c|c|c|c|c|}
\hline Breeds & $\begin{array}{l}\text { Insulin AUC } \\
\mu \mathrm{U} / \mathrm{min} \text { per } \mathrm{m} l\end{array}$ & $\begin{array}{l}\text { Glucagon AUC } \\
\mathrm{pg} / \mathrm{min} \text { per } \mathrm{ml}\end{array}$ & $\begin{array}{c}\mathrm{GH} A U C \\
\mathrm{ng} / \mathrm{min} \text { per } \mathrm{m} l\end{array}$ & $\begin{array}{c}\text { IGF-I AUC } \\
\mathrm{ng} / \mathrm{min} \text { per } \mathrm{m} l\end{array}$ & $\begin{array}{l}\text { Glucose AUC } \\
\mathrm{mg} / \mathrm{min} \text { per } \mathrm{d} l\end{array}$ & $\frac{\mathrm{K}}{\left(\times 10^{-4}\right)}$ \\
\hline $\begin{array}{l}\text { Japanese Black } \\
\text { heifers }\end{array}$ & $20.49 \pm 5.89^{\mathrm{a}}$ & $189.49 \pm 25.21^{\mathrm{a}}$ & $2.88 \pm 0.86^{a}$ & $53.38 \pm 14.90^{\mathrm{a}}$ & $72.31 \pm 9.49^{a}$ & 46. $60 \pm 17.16^{a}$ \\
\hline Holstein heifers & $16.20 \pm 3.29^{\mathrm{a}}$ & $154.80 \pm 3.90^{\mathrm{a}}$ & 4. $86 \pm 1.04^{\mathrm{a}}$ & $182.10 \pm 29.18^{b}$ & $78.97 \pm 3.94^{\mathrm{a}}$ & $70.69 \pm 2.34^{x}$ \\
\hline
\end{tabular}

Values are mean $\pm \mathrm{SE}$.

ab : Means within a column with different superscripts are different $(\mathrm{P}<0.05)$.

Table $1 \mathrm{~b}$. Summary of the area under the curve (AUC) of plasma insulin, glucagon, growth hormone $(\mathrm{GH})$, insulin-like growth factor I (IGF-I) at glucose responses to glucose challenges and rate of glucose disapperance rates $(\mathrm{K})$ in Holstein cows at mid lactation, late lactation and dry periods

\begin{tabular}{lcllclc}
\hline \hline $\begin{array}{c}\text { Stage of } \\
\text { lactation }\end{array}$ & $\begin{array}{c}\text { Insulin AUC } \\
\mu \mathrm{U} / \mathrm{min} \text { per } \mathrm{m} l\end{array}$ & $\begin{array}{l}\text { Glucagon AUC } \\
\mathrm{pg} / \mathrm{min} \text { per } \mathrm{m} l\end{array}$ & $\begin{array}{c}\text { GH AUC } \\
\mathrm{ng} / \mathrm{min} \text { per } \mathrm{m} l\end{array}$ & $\begin{array}{c}\text { IGF-I AUC } \\
\mathrm{ng} / \mathrm{min} \text { per } \mathrm{m} l\end{array}$ & $\begin{array}{c}\text { Glucose AUC } \\
\mathrm{mg} / \mathrm{min} \text { per } \mathrm{d} l\end{array}$ & $\begin{array}{c}\mathrm{K} \\
\left(\times 10^{-4}\right)\end{array}$ \\
\hline Dry stage & $13.38 \pm 1.92^{\mathrm{a}}$ & $141.27 \pm 3.92^{\mathrm{a}}$ & $4.73 \pm 0.56^{\mathrm{a}}$ & $126.79 \pm 28.76^{\mathrm{a}}$ & $82.88 \pm 2.63^{\mathrm{a}}$ & $75.53 \pm 9.97^{\mathrm{a}}$ \\
Middle stage & $9.13 \pm 2.28^{\mathrm{a}}$ & $177.69 \pm 14.30^{\mathrm{a}}$ & $7.37 \pm 1.08^{\mathrm{a}}$ & $51.03 \pm 7.54^{\mathrm{b}}$ & $72.94 \pm 3.43^{\mathrm{a}}$ & $76.37 \pm 5.58^{\mathrm{a}}$ \\
Late stage & $7.63 \pm 1.08^{\mathrm{a}}$ & $195.47 \pm 14.44^{\mathrm{a}}$ & $4.75 \pm 0.47^{\mathrm{a}}$ & $40.27 \pm 5.74^{\mathrm{b}}$ & $73.91 \pm 2.29^{\mathrm{a}}$ & $60.69 \pm 7.74^{\mathrm{a}}$ \\
\hline
\end{tabular}

Values are mean $\pm \mathrm{SE}$.

${ }^{\mathrm{ab}}$ : Means within a column with different superscripts are different $(\mathrm{P}<0.05)$. 
In $\mathrm{C}_{\mathrm{t}}=$ InC $_{0}-\mathrm{K} \times \mathrm{t}$

$C_{\mathrm{t}}$ はグルコース注入 $\mathrm{t}$ 分後の血墏グルコース濃度を示 し， $\mathrm{C}_{0}$ は $\mathrm{t}=0$ 時の血獎グルコース䕃度を示している， $\mathrm{K}$ は血等からの注入したグルコースの消头率を示してい る.

\section{統計処理}

表，グラフには平均値および標準誤差を示した，血獎 ホルモンの濃度の差については分散分析にて検定し, 有 意差のあるものについては多重比較検定（Sheffe 法）を 行った. また,グルコース注入前の值に対しての有意差 はStudent's $t$-test にて検定した.

\section{結果}

図1 aに末経産の黒毛和種牛とホルス夕イン種牛, 図 $1 \mathrm{~b}$ に乾乳期, 泌乳中期, 泌乳後期のホルスタイン種牛, それぞれの血墏インスリン，グルカゴン，GH, IGF-1, グ ルコース濃度変化を示した. また, 表 1 には各ホルモン， グルコースの AUC とグルコースの消失率（K）を示し た。

血漿インスリン濃度は未経産の黒毛和種牛とホルスタ イン種牛で注入後 15 分以内に最高值を示したあと速や かに下降した，ホルスタイン種の泌乳期間の比較では, 乾乳期のほうが泌乳期よりも高い濃度を継続した。イン スリンの AUC は泌乳期が進むにつれて低下した。 ま た, 品種の比較では黒毛和種牛のほうがホルスタイン種 牛上りあ大きい㑯向にあった。

血漿 $\mathrm{GH}$ 濃度は, 未経産の黑毛和種牛とホルスタイン 種牛では，ともに注入後 30 分以内に最高值を示したあ と速やかに下降し，類似の变動走した，泌乳期間の比 較では，乾乳期のほらが泌乳期よりも高い濃度を継続し た. GH の AUC 洁泌乳中期が他の時期よりも大きい傾 向にあった。 また, 品種の比較ではホルスタイン種のほ うが黒毛和種よりあ大きかった。

血漿 IGF-I 濃度は，グルコース注入により，それぞれ の品種および泌乳期に抢いて有意な変動は認められな

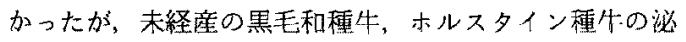
乳中期上泌乳後期に比べホルスタイン種牛乾乳期で高 かった。また，IGF-Iの AUC は品種間の比較でホルス タイン種牛が黑毛和種牛に比べ有意に大き加った。

血漿グルカゴン濃度は, 品㯖間の比較で黒毛和種牛之 ホルスタイン種牛どちらすグルコース注入後 15 分以内 に低值を示したあと速やかに上昇した，実駼期間中，黒 毛和種牛のほうが高い濃度であった，泌乳期の比较で は，乾乳期より泌乳期の浱度が高加った。AUC は泌乳 期が進むにつれて増加した，また, 品種の比較では黒毛
和種のほうがホルスタイン種よりあ大きかった。

血漿グルコース濃度は, 品種間の比較では, 木ルスタ イン種条経座牛のほうがグルコースの静脈内注入に対す る反応が大きかった，泌乳期の比較では，泌乳後期が他 の泌乳期上りあ消失率が小さい傾向が認められた。

\section{考察}

反留動物のみならず泌乳を行う動物では，泌乳，妊娠 時には乳生産や胎子の成長のためエネルギーと基質の要 求量が增加する. そのため, 体内での栄養素の利用とそ の分配が变化することが知られており するホルモンの中でもインスリンの血嶈濃度は, 泌乳時 に低く，乳用牛のほうが肉用牛上りあ低( $\left(^{8)}\right.$ ことが報告 されている。本実験においては，グルコース注入刺激に 対するインスリン分必能は未経産の乳用種であるホルス タイン種牛に比べ，肉用㮔である黒毛和種牛で高い傾向 にあったグルコースに対する反応は，ウシの月齢に よっても变わること占，ヒッジでは成長に従い低下する ことが報告されている゙が，本実験では両種とすに同一 月齢であるこよからインスリン分泌能の差は品種間差で ある可能性が大きい，乳用種の泌乳期のインスリン分泌 能の比較では乳量の多い泌乳中期に最も低く, 乳量が減 少する泌乳後期にはインスリン分泌能は高くなり, 乾乳 期で最む高い㥧向にあった，品種間のインスリン分泌能 の比較では，肉用種である黒毛和種でやや高い傾向がみ られたが，これは改良の目的として脂肪の蓄積を中心に 改良がなされた結果，栄養素の同化作用にすぐれ，その 結果, 黒毛和種4-で同化作用のあるインスリンの分泌能 は産乳を中心に改良されたホルスタイン種牛とは異なっ たと考えら机た，さらに，反塲動物は必要とされるグル コースを飼料から直接得にくいた奻，乳腺での乳合成の ためのグルコース利用量が增す泌乳期には，インスリン 分泌を少くすることで, 乳腺以外の末梢組織の筋組織や 脂肪組織におけるグルコースの利用を少なくしていると 考えられた。

グルカゴンは，今回の結果では黑毛和種で分泌能が高 かった。この理由として黑毛和種は脂肪蓄積の効率を中 心に改良した品種であり，その結果，末梢組織の符組織 や脂肪組織でグルコースがよく利用されるようにインス リン分泌が促進される一方, 紡代谢の恒常性維持のため 糖新生作用のある9)グルカゴン分泌が高くなったと考え られた。

糖新生において， $\mathrm{GH}$ す重要な㗢きをしていると考え られている.グルコース注入刺激に詨する $\mathrm{GH}$ 分泌能 は, 品種間の此較ではホルスタイン種牛のほうが黒毛和 
佐藤・干葉・武田・萩野
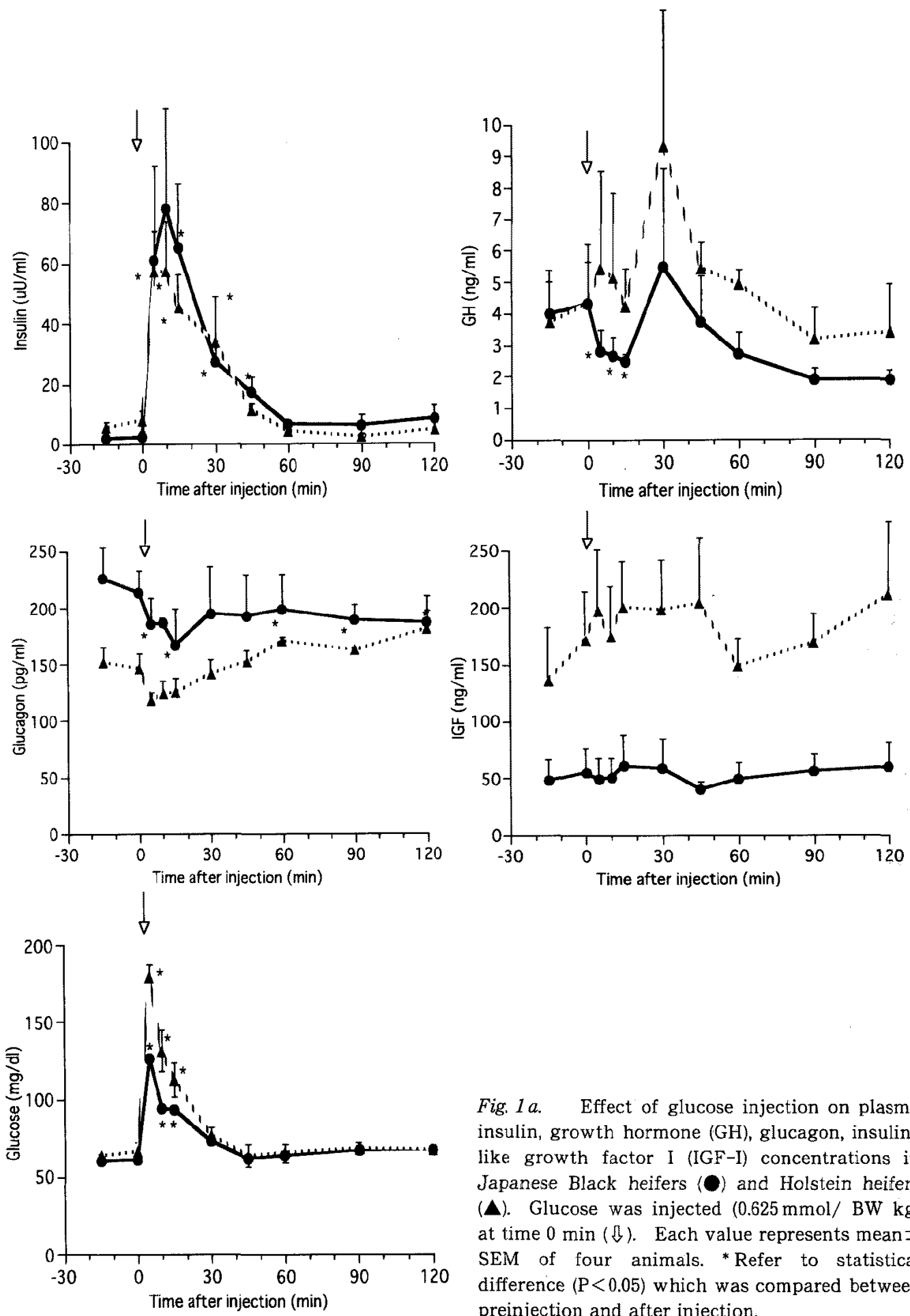

Fig. 1a. Effect of glucose injection on plasma insulin, growth hormone (GH), glucagon, insulinlike growth factor I (IGF-I) concentrations in Japanese Black heifers (O) and Holstein heifers (A). Glucose was injected $(0.625 \mathrm{mmol} / \mathrm{BW} \mathrm{kg})$ at time $0 \min (\S)$. Each value represents mean \pm SEM of four animals. ${ }^{*}$ Refer to statistical difference $(P<0.05)$ which was compared between preinjection and after injection. 

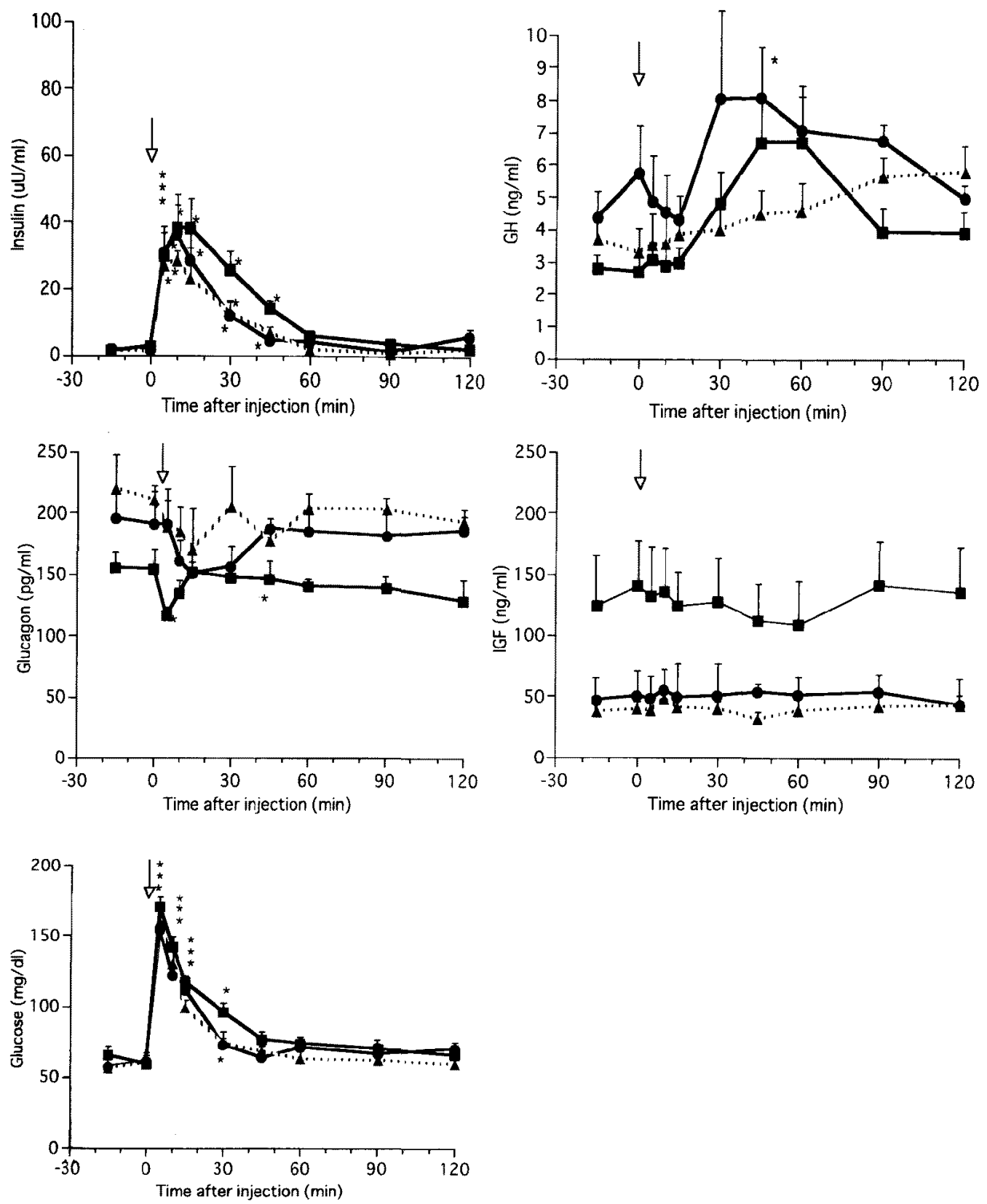

Fig. $1 \mathrm{~b}$. Effect of glucose injection on plasma insulin, growth hormone (GH), glucagon, insulin-like growth factor I (IGF-I) concentrations in Holstein cows at mid lactation (O), late

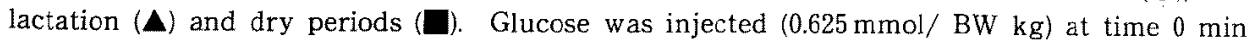
(ई). Each value represents mean $\pm S E M$ of four animals. * Refer to statistical difference $(\mathrm{P}<$ $0.05)$ which was compared between preinjection and after injection. 
種牛よりも高かった：これは頲伝的に大型の品種で高い とする報告 15,23$)$ と同梯の結果である.さらに, 黒毛和種 牛は脂肪蓄皘を中心に改良された品種であるためにイン スリンの同化作用を優先し，抗インスリン作用を持つ GH $の$ 分泌能が低かったことも推测される，GH の基礎 レベルは，泌乳の開始によって高まることが報告されて

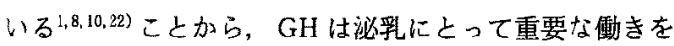
していることが予想されたが，今回の実験でグルコース 負荷に対する $\mathrm{GH}$ 分泌能は泌乳中期で高かった．これは 乳腺での泌乳に必要なエネルギーをま加なうため，末梢 組織でのグルコース利用を揤制するために $\mathrm{GH}$ 分泌能 が高かったと考えられた。

インスリン,グルカゴン，GH は, 糖代謝以外にも脂質 代謝，タンパク蛋白代謝等にも深く関わっているため, これらのホルモンの関わり合いを脂質代謝, タンパク代 謝加検討し, 品種間差, 泌乳期間差を明らかにする必 要がある。

IGF-I はGH の刺激によって分泌が調節されることが 知られており"), GH の濃度が低下すれば IGF-I 濃度む 低下すると考えられている。これらのことから，品種間 の比較で, 成長度の大きい本ルスタイン種牛において IGF-I濃度が高かったと考えられた，他方，IGF-I 持摄 取エネルギーの影響も受けるとされ，摄取エネルギー不 足時には低く，GH が逆に高いこと年，Keys ら"1)が， IGF-I の生理作用を調節している，GH が脂肪代謝等を通 し，不足エネルギーの調節に関与していることを報告し ていることから，泌乳期には泌乳のためにその摄取栄養 エネルギーを最大限乳生産に向けるため摄取エネルギー が不足していることが推測された。このエネルギー不足 汃, 泌乳期か乾乳期に比心 IGF-I 濃度加低い要因の一つ である可能性がある。

以上の結果，ウシは主な栄養素であるグルコースの静 脈内注入に対し, 品種, 泌乳期で代謝ホルモンが各目的 に適合した固有の反庒を示すことが示唆された。

\section{謝辞}

本実験を実施するにあたり，御指導をいただいた東北 大学農学部佐々木康之教授, 実験補助, 動物の管理をし ていただいた当場酪農肉牛部職員ならびに奥山竹子さ ん，千葉 綾さんに深謝の意を表します。

\section{文献}

1) Bines JA, Hart IC. Metabolic limits to milk production, especially roles of growth hormone and insulin. J. Dairy Sci., 65 : 1375-1389.
1982.

2) Breier BH, Bas JJ, Butler JH and Gluckman PD. The somatotrophic axis in young steers: influence of nutritional status on pulsatile release of growth hormone and circulating concentrations of insulin like growth factor I.J. Endcrinol., 111 : 209-215. 1986.

3) Collier RJ, McNamara JP, Wallace CR, Dehoff MH. A review of endocrine regulation of metabolism during lactation. J. Anim. Sci., 59 : 498-510. 1984.

4) Froesch ER, Schmid C, Schwander J, Zaph J. Action of insulin like growth factors. Ann. Rev. Physiol., 47 : 443-467. 1985.

5) Gray DG, Unruh JA, Dikeman ME and Stevenson JS. Implanting young bulls with zeranol from birth to four slaughter ages; 3 . Growth performance and endocrine aspects. J. Anim. Sci., $63:$ 747-756. 1986.

6) Grigsby ME, Trenkle A. Plasma growth hormone, insulin, glucocorticoids and thyroid hormones in large, medium and small breeds of steers with and without an estradiol implant. Domest. Anim. Endocrinol., 3: 261-267. 1986.

7) Grizard J, Szczygiel M, Champredon C, Theriez M, Prugnaud J, Pion R. Response of blood glucose and free amino acid concentrations to insulin administration in growing sheep. Nutr. Rep. Int., 36 : 241-251. 1987.

8) Hart IC, Bines JA, Morant SV, Ridley JL. Endocrine control of energy metabolism in cow: comparison of the levels of hormones prolactin, growth hormone, insulin and thyroxine and metabolites in high-and low-yielding cattle at various stages of lactation. J. Endocrinol., $77:$ 333-345. 1978.

9) Herbein JH, Aiello RJ, Eckler LI, Pearson RE, Akers RM. Glucagon, insulin, growth hormone, and glucose concentrations in blood plasma of lactation dairy cows. J. Dairy Sci., $68: 320-325.1985$.

10) Kaprowski, JA, Tucker HA. Bovine serum growth hormone, corticoids and insulin during lactation. Endocrinology, $93: 645-651,1973$.

11) Keys JE, Capuco AV, Effect of bovine growth hormone (bGH) on acetate incorporation by mammary and adipose tissue from Holsteins at different stages of first term gestation and lactation. J. Dairy Sci., $68: 106.1985$.

12）農林水産省農林水産技術会議事務局編，日本飼養 標準肉用牛. 中央畜産会. 東京. 1987.

13）農林水産省農林水産技術会議事務局編. 日本飼養 標準乳用牛. 中央畜産会. 東京. 1987. 
14) Oda $S$, Satoh $H$, Sugawara $T$, Matunaga $N$, Kuhara T, Katoh K, Shoji Y, Nihei A, Ohta M, Sasaki Y. Insulin-like growth factor I, GH, Insulin and glucagon concentrations in bovine colostrum and in plasma of dairy cows and neonatal calves around parturition. Comp. Biochem. Physiol., 94 A : 805-808. 1989.

15) Ohison DL, Davis SL, Ferrel CL, Jenkins TG. Plasma growth hormone, prolactine and thyrotropin secretory patterns in Hereford and Simmental calves. J. Anim. Sci., 53 : 371375. 1981.

16) Oneda A, Ishii S, Horigome K, Yamagata $S$, Glucagon response to arginine after treatment of diabetes mellitus. Diabetes., $24: 811-819$. 1975.

17) Peel CJ, Bauman DE. Somatotropin and lactation. J. Dairy Sci., 70:474-486. 1987.

18) Reynaert R, Paepe M, Marcus S, Peeters G. Influence of serum free fatty acid levels on growth hormone secretion in lactating cow. J. Endocrinol., 66 : 213-224. 1975.
19) Sartin JL, Cummins KA, Kemppainen RJ, Marple DN, Rahe CH, Williams JC. Glucagon, insulin, growth hormone responses to glucose infusion in lactating dairy cow. Am. J. Physiol., 248: E 108-E114. 1985.

20) Sasaki $Y$, Takahashi H. Insulin secretion in sheep exposed to cold. J. Physiol., $306: 323-335$. 1980.

21) Smith RD, Hansel W, Coppice CE. Plasma growth hormone and insulin during early lactation in cows fed silage based diet. J. Dairy Sci., 59 : $248-254.1975$.

22) Vasilatos $R$, Wangness PJ. Diural variation in plasma insulin and growth hormone associated with two stages of lactation in high producting cows. Endocrinology, $108: 300-304$. 1981.

23) Verde LS, Trenkle A. Concentrations of hormones in plasma from cattle with different growth potentials. J. Anim. Sci., 64 : 426-432. 1987. 


\title{
Hormone Responses to Glucose Injection in Japanese Black Cattle and Holstein Cattle
}

\author{
Hidetoshi SATOH*, Kazuyoshi CHIBA, \\ Masanori TAKEDA and Akihiko HAGINO'1) \\ Miyagi prefectural animal industry experiment station, Iwadeyama-machi, \\ Miyagi-ken $989-6445$ \\ 1) Faculty of agriculture, Tohoku University, Aoba-ku, Sendai-shi $981-0914$
}

\begin{abstract}
We compared the change in the concentration of hormones retracted to nutrient utilization and metabolism following intravenous glucose injection between Japanese Black beef heifers, Holstein heifers and dairy cows. Additionally, we examined how these responses changed in each breed as lactation progressed. Plasma concentrations of insulin, glucagon and growth hormone were significantly affected by the glucose injection. However, there was no significant effect on concentrations of insulin-like growth factor I (IGF-I). The responses were similar to those observed in Japanese Black and Holstein heifers. The area under the curve (AUC) of insulin and glucagon were greater for the Japanese Black heifers, while the AUC of growth hormone (GH) and insulin was lower for the Holstein cows. The AUC of insulin and glucagon increased with lactation, while those of GH and IGF-I decreased. The result demonstrated that the utilization of glucose and the hormone responses to glucose injection were different between breeds and stage of lactation.
\end{abstract}

Anim. Sci. Technol. (Jpn.) 69 (5) : 475-482, 1998

Key words : Japanese Black heifer, Holstein cattle, Gluconeogenesis, Stage of lactation, Metabolic hormone

* Present address : Hasama Agriculture Extention Center, Hasama-cho, Miyagi-ken 987-0511 